\title{
THE INFLUENCE OF UNPLANNED TECHNICAL SERVICES ON AIRCRAFT FLEET'S MANAGEMENT
}

\section{WPLYW PRZEGLĄDÓW NIEPLANOWYCH NA PROCES ZARZĄDZANIA FLOTĄ STATKÓW POWIETRZNYCH}

\author{
Artur Kierzkowski \\ Wroclaw University of Technology, Faculty of Mechanical Engineering \\ 50-371 Wrocław Łukasiewicza 5 \\ e-mail: artur.kierzkowski@pwr.wroc.pl
}

\begin{abstract}
In this paper the influence of introduced airworthiness directives and bulletin services on in-service process were described. During the in-service time two main states can be distinguished: exploitation and service. An aircraft is an example of technical object in which exists strong relations between these states. The main aim of any airline is to maximize its profits. Such an optimization is affected by several factors. They are mainly connected to the service state (service cost minimization) as well as to the exploitation state (flight interval minimization, frequency ratio maximization, work waiting time minimization, etc.)
\end{abstract}

Keywords: Low Cost Carriers, aircraft, maintenance, scheduling,

Streszczenie: $W$ referacie zostanie zaprezentowany sposób poprawnego planowania prac obstugowych oraz wptyw wprowadzenia dyrektyw zdatności $i$ serwisów biuletynowych na proces eksploatacji statku powietrznego. $W$ procesie eksploatacji obiektu technicznego istnieja dwa główne stany: użytkowania oraz obstugiwania. Statek powietrzny jest obiektem technicznym w którym istnieja silne relacje pomiędzy tymi stanami. Głównym celem linii lotniczej jest maksymalizacja zysków. Na taka optymalizację wplywa kilka czynników. Czynniki te zwiąane sa ze stanem obstugiwania (minimalizacja kosztów obstugi technicznej), jak również w dużym stopniu ze stanem użtkowania (minimalizacja czasów pomiędzy lotami, maksymalizacja wskaźnika wypetnienia statku powietrznego, minimalizacja czasu oczekiwania statku powietrznego na wykonywanie pracy przewozowej itp.).

Stowa kluczowe: Tanie Linie Lotnicze, samolot, przeglady techniczne, planowanie 


\section{Introduction}

The issue of air fleet service management is a very complex question. It was described in detail in [1] and [2]. It also depends on the specific attributes of each airline. Low cost airlines do not possess their own service stations. Planning air connection net is related to the location of service stations. Airports can be divided into the following categories:

- airports, in which base services are performed (base service makes airplane disabled for a few days)

- airports, in which line services are performed (line service makes airplane disabled for a few hours)

- airports, in which night stays take place - waiting for new transportation tasks

- airports, to which only air connection are serviced - airplanes do not have there neither night stays nor any kind of maintenance works.

The time of performing base service and line service depends on three factors: the length of flight (in time), the number of takeoffs and the number of days since the previous service [3]. The time moment of performing each category of service is changeable in time. It is crucial to plan them properly in the whole exploitation process [4]. The values, which determine the time of performing each kind of service, are definite.

Apart from a planned service schedule there also exist some methods of introducing changes in the whole service process. It is determined by the safety reasons. There are two main ways of introducing additional service activities. One of them is to keep the bulletin by the owner of the type certificate. The second way is to introduce the airworthiness directives by EASA. They show the activities which should be performed during the additional service, their time-limit as well as their frequency.

\section{Airworthiness directives}

The specific nature of air transport, the small probability of surviving air disaster as well as its consequences, especially on the densely populated areas, lead to the strict discipline in performing technical services in order to minimize the risk of any kind of damage. Each airplane has its own service instruction (Aircraft Maintenance Program). This instruction lists all the periodic works, which an airplane should undergo. In case of appearing the damages of the same type in an airplane, the EASA might introduce a new directive, which enforces the airline to perform some additional services. These directives may concern airplanes or their components as well. The 
airworthiness directive may be introduced for an engine of each type, then the additional service concerns only airplanes with this type of engine. The similar situation takes place with other components or devices, which are not installed in airplanes in series. The airworthiness directives may introduce single service activity, but mostly these activities are repeatable (periodic).

Publishing the airworthiness directives may result in changes in schedule of maintenance works.

The figure 1 shows histogram of number of days in which the air carrier has to perform not scheduled technical service, caused by publishing of the airworthiness directives for the plane Airbus 320.

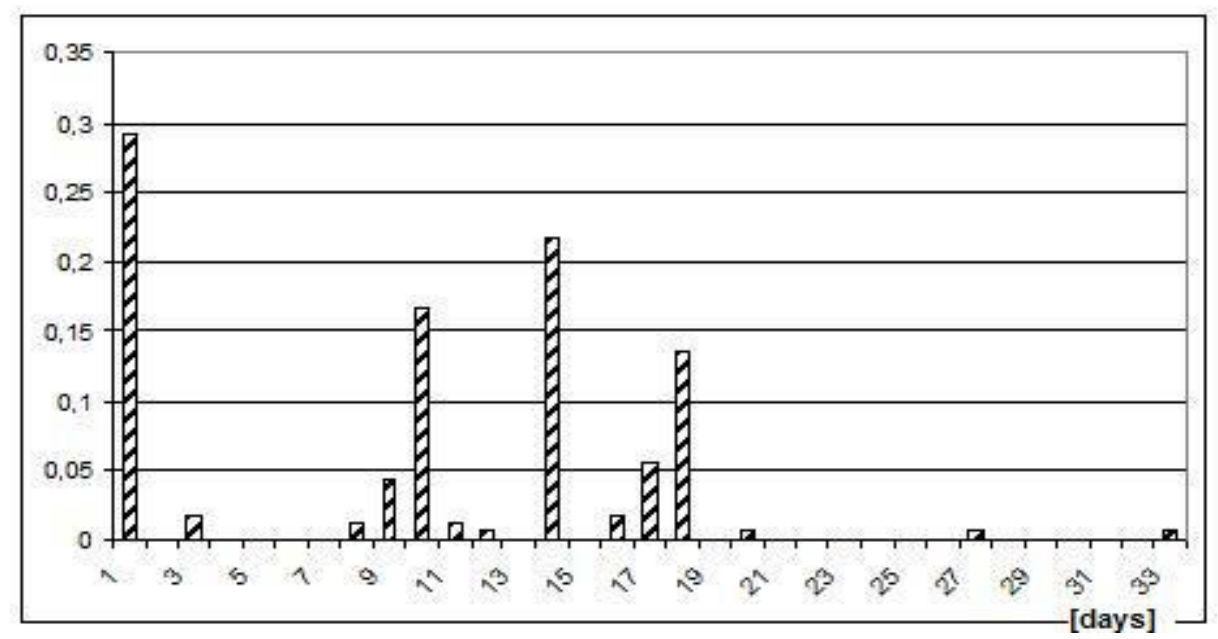

Fig. 1 Histogram of number of days in which the air carrier has to perform not scheduled technical service, caused by publishing of the airworthiness directives for the plane Airbus 320. Own elaboration, based on [5].

It should be noticed that the most probable situation is introduction of airworthiness directives for the plane Airbus 320 with the status Emergency ("E"), what means enforceable forthwith. Introducing such airworthiness directives in the day $\mathrm{X}$, enforce the carrier to execute technical service to the day $\mathrm{X}+1$.

Not planned technical works have an extreme effect on the exploitation process of airplanes (particularly important are service E - type). The crucial factor influencing on air disturbances is the length of each service activity (in time). Figure 2 shows the relation between the number of days in which the carrier has to execute service works and the time of their execution. 


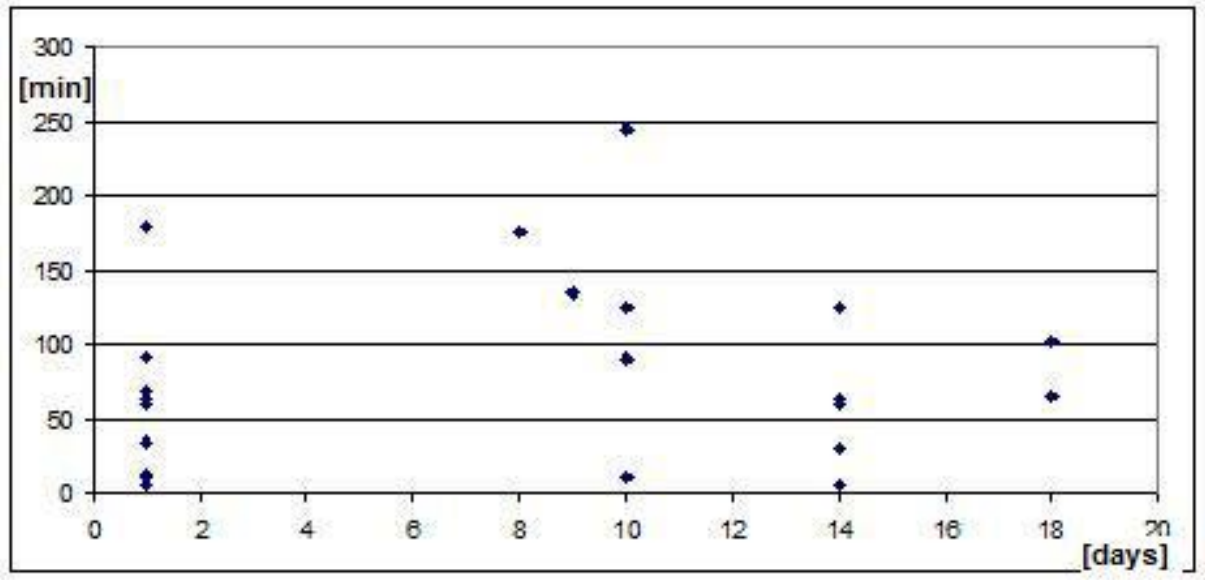

Fig. 2 The graph illustrating the relation between the number of days in which the carrier has to execute service works and the time of their execution. Own elaboration, based on [6].

The most problematic is to execute the airworthiness directives with enforceable forthwith status, which have long time of realization. The influence of such directives has been described in chapter 4 .

It is crucial to analyze the repeatability of airworthiness directives and their coincidention with periodical inspections. In case of air carrier with a great number of flights (e.g.: low cost airlines) and if the night stays last only a few hours, then it is sensible to minimize the number of mile inspections.

Unfortunately, the airworthiness directives are not corresponding to the interval of mile inspections. It enforces a proper plan of repeatable airworthiness directives in the whole exploitation process.

\section{Bulletin services}

After bringing an airship to operation the owner of the type certificate starts monitoring its exploitation. All the services planned during the project works are observed day by day. Base services [6] are performed only in service station with authorization. Their staff has gained necessary experience and posses all the obligatory equipment. The execution time of such a service may last even one week. An airplane has to be checked in detail. All its components are serviced. Having noticed that there is a real probability of arising any kind of damage for each component, the owner of the type certificate publishes the bulletin service. This service orders to check the component in all the airplanes of this type. The similar situation happens with other technical services (e.g.: line services).

The histogram for the airplane Airbus 320 shows figure 3 . 
The influence of unplanned technical services on aircraft fleet's management 251 Wptyw przegladów nieplanowych na proces zarzadzania ....

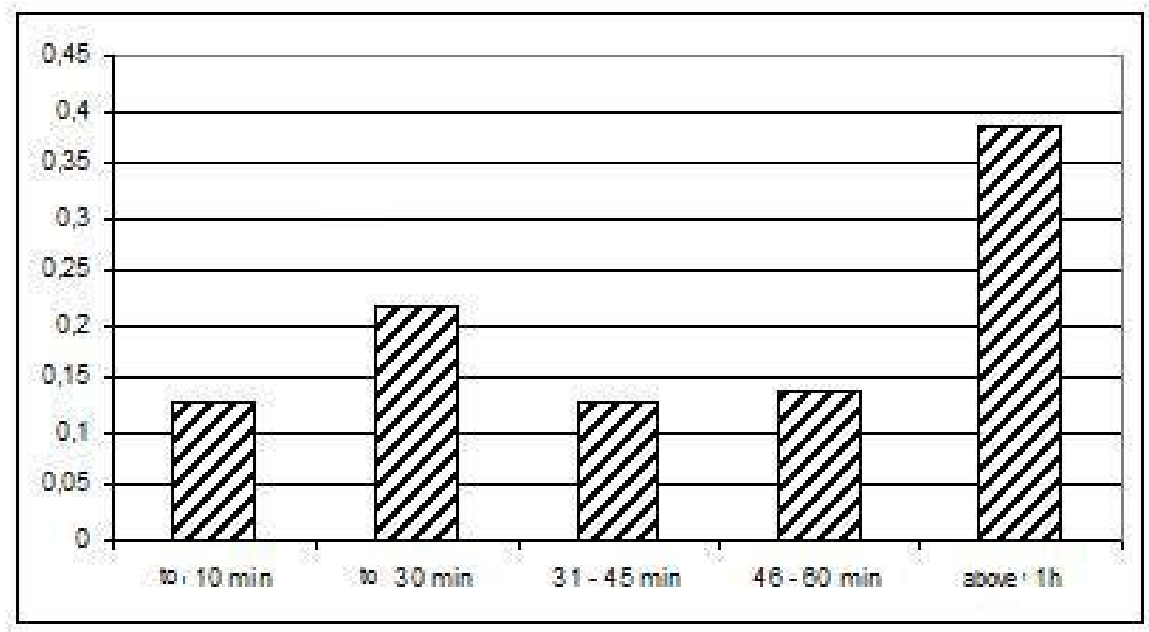

Fig. 3 The frequency graph of technical activities.

Own elaboration, based on [6].

Some complications in the flying capability management process happen not only in different types of airplanes, but they also arise in planes of the same type but with different component or equipment. This case happens for example with planes Airbus 320. Some of airplanes have engines type CFM56 and the others V2500. This situation enforces the introduction of two different Technical Maintenance Programs.

The histogram for each engine shows figure 4.



Fig. 4 The frequency graph of technical service duration, based on bulletin services used in Airbus 320. Own elaboration, based on [4]. 
Taking into consideration operation viewpoint it should be noticed that the engines of these types have essential differences in their technical service. Moreover, please note that in case of the engine CFM 56 the duration of service, demanded by the bulletin service, has a higher frequency in the time interval up to 30 minutes. It should be highlighted that more than $25 \%$ of bulletin services related to engine V2500 are performed longer than 1 hour. When introducing repeatable bulletin services, the interval for each engine should be defined. Longer technical service times, caused by bulletin services, can have significantly longer intervals, even 6000 hours of flight or 18 months. In order to obtain detailed analysis it will be necessary to perform the analysis similar to this one in case of airworthiness directives. The elaboration showing the relation between the number of days in which the carrier has to perform activities demanded by bulletin service and their duration would be essential.

\section{The influence of unplanned technical cervices on the exploitation process of airplanes}

The influence of introduced airworthiness directives and bulletin services on the exploitation process of aircrafts depend on the specific attributes of each airline. In case of Low Cost Airlines the situation is much complex in comparison to traditional airlines. Low Cost Airlines operate to regional airports. The characteristic attributes of airports have been discussed in chapter 1. Let's assume that the air carrier possesses two aircrafts (AC1 and $\mathrm{AC} 2$ ) and that it operates between four airports (A, B, C and D). The airports $\mathrm{B}, \mathrm{C}$ and $\mathrm{D}$ are the airports, where aircrafts may spend their night stays. The airport A is the airport where technical services are performed. The figure 5 shows the exploitation process of two airplanes during two days.

\begin{tabular}{|c|c|c|c|c|c|}
\hline & 6.00 & 12.00 & 18.00 & 24.00 & 6.00 \\
\hline $\mathrm{AC} 1$ &  & 00 & $\bar{c}$ & $\sqrt{c}$ & B \\
\hline AC2 & c & $\overline{0}$ & 5 & 再 & $A$ \\
\hline & 6.00 & $\mid 12.00$ & $\mid 18.00$ & $\mid 24.00$ & 6.00 \\
\hline $\mathrm{AC} 1$ & & $\bar{A}$ & 0 & $\bar{c}[\mathrm{c}$ & \\
\hline$A C 2$ & $=0$ & $\bar{c} \sqrt{c}$ & 0 & 西 & $\bar{B}$ \\
\hline
\end{tabular}

Fig. 5 The exploitation process of two airplanes during the two following days. 
In the figure 6 the moments of airworthiness directives have been marked. Introducing these directives enforces their immediate execution (up to the day $\mathrm{X}+1)$. Their duration is about 4 hours.

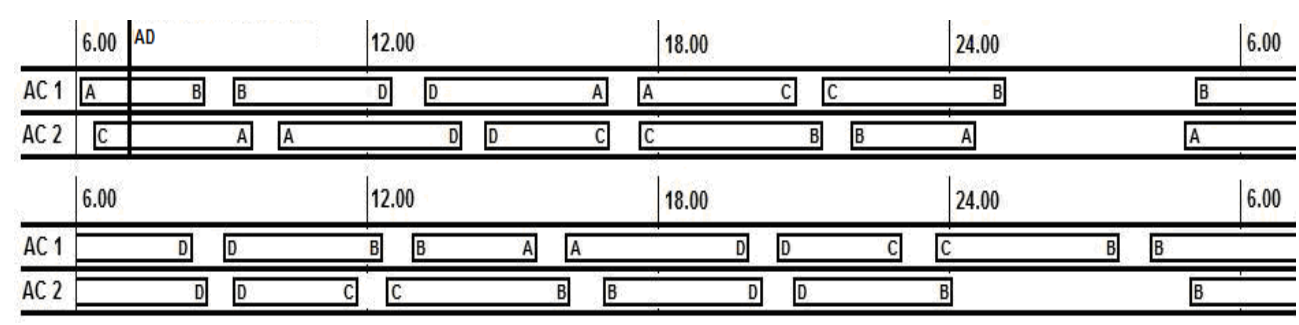

Fig. 6 The moment of introducing airworthiness directives

Considering the case of aircraft AC2 the technical service following worthiness directives may be executed during the night stay. The problem arises in case of aircraft $\mathrm{AC} 1$, because night stay takes place in airport, where the technical service cannot be performed. As a result, it is necessary to plan the technical service in the airport A. Unfortunately, in the case of aircraft $\mathrm{AC} 1$ the directive's execution will cause delays (fig. 7).



Fig. 7 The changes in the air connection net caused by the introduction of airworthiness directive

The delayed flights in figure 7 shaded. The technical service performed for the plane $\mathrm{ACl}$ caused flights' delays from the airport $\mathrm{A}$ to $\mathrm{C}$ and from the airport $\mathrm{C}$ to $\mathrm{B}$, which amount to $4 \mathrm{~h}$. If the technical service lasted longer than $4 \mathrm{~h}$, than the delays would be transferred to all the flights in the next day.

\section{Conclusion}

The paper deals with the issue of introducing unplanned technical services (because of the airworthiness directives and bulletin services)in the exploitation process of aircraft. It has been discussed the main questions, which should be considered while analyzing unplanned mile inspections. It 
has been pointed out the influence of airworthiness directives on the set air connection net.

The further works will concentrate on possibilities of modification the set air connection net in the case of introducing unplanned technical services. Such a modification will aim at minimizing delays. The considered net will take into account two stochastic factors.

\section{Bibliography}

[1] - Kierzkowski A.: Analiza funkcjonowania Tanich Linii Lotniczych Logistyka 2/2008

[2] - Kierzkowski A.: Problems of identification of operation processes for low cost carriers - Journal of Konbin vol. 3, nr 3, s.281-287, 2008.

[3] - Desaulniers. G.: Daily aircraft routing and scheduling. Management Science 43, 841-855, 1997.

[4] - Sriram C., Haghani A.: An optimization model for aircraft maintenance scheduling and re-assignment. Transportation Research Part A 37, 29-48, 2003.

[5] - http://ad.easa.europa.eu

[6] - Maintenance Planning Dokument for Airbus 318/319/320/321 rev. 29.

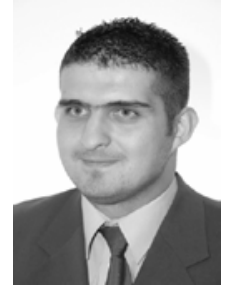

Artur Kierzkowski MSc. Eng. University of Technology Wroclaw. Research work includes most important questions related with specificity of low cost airlines' operation. Presently I deal with optimization of transport process. 